\title{
Expression pattern of matrix metalloproteinases in human gynecological cancer cell lines
}

\author{
Andrea Schröpfer, Ulrike Kammerer, Michaela Kapp, Johannes Dietl, Sonja Feix, Jelena Anacker*
}

\begin{abstract}
Background: Matrix metalloproteinases (MMPs) are involved in the degradation of protein components of the extracellular matrix and thus play an important role in tumor invasion and metastasis. Their expression is related to the progression of gynecological cancers (e.g. endometrial, cervical or ovarian carcinoma). In this study we investigated the expression pattern of the $23 \mathrm{MMPs}$, currently known in humans, in different gynecological cancer cell lines.

Methods: In total, cell lines from three endometrium carcinomas (Ishikawa, HEC-1-A, AN3 CA), three cervical carcinomas (HeLa, Caski, SiHa), three chorioncarcinomas (JEG, JAR, BeWo), two ovarian cancers (BG-1, OAW-42) and one teratocarcinoma (PA-1) were examined. The expression of MMPs was analyzed by RT-PCR, Western blot and gelatin zymography.

Results: We demonstrated that the cell lines examined can constitutively express a wide variety of MMPs on mRNA and protein level. While MMP-2, $-11,-14$ and -24 were widely expressed, no expression was seen for MMP-12, $-16,-20$, $-25,-26,-27$ in any of the cell lines. A broad range of 16 MMPs could be found in the PA1 cells and thus this cell line could be used as a positive control for general MMP experiments. While the three cervical cancer cell lines expressed 10-14 different MMPs, the median expression in endometrial and choriocarcinoma cells was 7 different enzymes. The two investigated ovarian cancer cell lines showed a distinctive difference in the number of expressed MMPs (2 vs. 10).

Conclusions: Ishikawa, Caski, OAW-42 and BeWo cell lines could be the best choice for all future experiments on MMP regulation and their role in endometrial, cervical, ovarian or choriocarcinoma development, whereas the teratocarcinoma cell line PA1 could be used as a positive control for general MMP experiments.
\end{abstract}

\section{Background}

Tumor invasion and metastasis define malignancy and are the principal causes of cancer associated death. Tumor cells are surrounded by the extracellular matrix (ECM) comprising of proteoglycanes and non-proteoglycanic matrix components (collagen, laminin, fibronectin and elastin). Degradation of the extracellular matrix allows tumor cells to detach from the primary tumor mass, invade local tissue, intravasate, extravasate and build new metastatic formations [1]. Currently, four classes of proteinases are known as being capable of breaking down nearly all components of the extracellular matrix: serine proteinases, aspartatic proteases, cystein proteinases and matrix metalloproteinases (MMPs) [2-4]. Previous studies showed that MMPs facilitate tumor

\footnotetext{
*Correspondence: Stojic_J@klinik.uni-wuerzburg.de

Department of Obstetrics and Gynecology, University of Wuerzburg, JosefSchneider Str. 4, 97080 Wuerzburg, Germany
}

invasion and metastasis in general. Compared to normal tissue, in almost all human cancers the expression and activation of MMPs is increased [5,6]. Also, MMPs play a role in a multiplicity of physiological processes requiring tissue remodeling (e.g. wound-healing, embryogenesis, angiogenesis and ovulation) [2-4]. There is a precise regulation between activation and inhibition of proteolysis and this physiological balance seems to be disrupted in cancer [7].

MMPs are a family of structural and functional related endopeptidases. Currently, 23 members of the MMP family are known in humans [2]. MMPs are zinc dependent proteases which are capable of degrading one or more components of the extracellular matrix. Depending on their substrate specificity, MMPs are divided into six subclasses: collagenases, gelatinases, stromelysins, matrilysins, membrane-type MMPs and others [2]. MMPs are synthesized as inactive zymogens. First they remain 
inactive by an interaction between the prodomain and the zinc-ion bound to the catalytic site. After removal of the propeptide domain, the active site becomes available to cleave substrates. All MMPs, except MMP-11, are secreted as inactive zymogens and are activated outside the cell by other activated MMPs or serine proteases (e.g trypsin, plasmin, kallikrein) [2-4]. Under physiological conditions, expression of MMPs is tightly regulated on an mRNA level (transcription), e.g. activation of MMPs and inhibition of active MMPs by TIMPs (tissue inhibitors of MMPs).

There is evidence, that the expression of MMPs is related to the progression of gynecological cancers, as is such the case for endometrium cancer [8,9], cervical carcinoma [10-13] and ovarian carcinoma [14-17]. However, only a few MMP-members were investigated in these previous studies. In order to enlarge the knowledge on the role of MMPs plays in these cancer entities, we investigated the expression of all MMPs known in humans so far by measuring mRNA and protein level in twelve gynecological cancer cell lines commonly used in experimental research. We examined cell lines of endometrium carcinoma (Ishikawa, HEC-1-A, AN3 CA), cervix-carcinoma (HeLa, Caski, SiHa), chorioncarcinoma (JEG, JAR, BeWo), ovarian cancer (BG-1, OAW-42) and the teratocarcinoma cell line PA-1.

Until now, only limited data are available on the expression of MMPs in the cell lines investigated herein. Giambernardi and colleagues found the expression of MMP-7, $-14,-15,-16$ and -17 in HeLa cells on mRNA level as well as an expression of MMP-12 and MMP-14 mRNAs in JEG cell line using RT-PCR [18]. MMP-14 was also detected in the cervix-carcinoma cell lines Caski and $\mathrm{SiHa}$ [19]. For an overview, data published so far are summarized in Additional file 1: MMP expression in gynecological cancer cell lines.

\section{Methods}

\section{Cell culture}

All the cell lines used were described in Table 1 [20-45] and obtained from Cell Lines Service (Eppelheim, Germany). Briefly, all cells were cultured in a 1:1 mixture of DMEM/Ham's F-12 supplemented with $10 \%$ FCS and $10 \mathrm{ng} / \mathrm{ml}$ gentamycine (PAA, Coelbe, Germany) at $37^{\circ} \mathrm{C}$ in the presence of $5 \% \mathrm{CO}_{2}$. Cells were cultured in $75 \mathrm{ml}$ culture-flasks (Biochrom, Berlin, Germany) as monolayer culture and harvested at $80-90 \%$ confluency using a cellscraper (Biochrom). Cells were resuspended and washed twice in phosphate-buffered saline (PBS). Dry pellets were frozen at $-20^{\circ} \mathrm{C}$ for RNA and protein extraction.

\section{RNA extraction and CDNA synthesis}

Total RNA was extracted from $10^{6}$ cells using RNeasy mini kit (Qiagen, Hilden, Germany) according to the manufacturer's instruction. Total cellular RNA was eluted in $60 \mu \mathrm{l}$ RNase free water and stored at $-20^{\circ} \mathrm{C}$. Total RNA was transcribed at $42^{\circ} \mathrm{C}$ for $1 \mathrm{~h}$ in a $20 \mu \mathrm{l}$ reaction mixture using the RevertAid $\mathrm{H}$ Minus First Strand cDNA synthesis kit (Fermentas, St. Leon-Rot, Germany) and terminated by heating the samples at $70^{\circ} \mathrm{C}$ for $10 \mathrm{~min}$. Synthesized cDNAs were stored at $-20^{\circ} \mathrm{C}$ for further expression analysis.

\section{Semiquantitative RT-PCR}

Expression analyses of MMPs were performed using gene specific primers and optimized reaction conditions as published previously [46]. Conventional PCR reactions were performed in a volume of $25 \mu \mathrm{l}$ containing template DNA, $2.5 \mathrm{U}$ Taq polymerase, $10 \mathrm{X}$ reaction buffer with $1.5 \mathrm{mM} \mathrm{MgCl}_{2}$ (Eppendorf, Hamburg, Germany), $200 \mu \mathrm{M}$ dNTPs (Fermentas), $0.4 \mu \mathrm{M}$ of both forward and reverse primers and formamide at a final concentration of $4 \%$. PCR conditions were optimized for each primerpair. Amplification reactions were performed using a Px2 thermal cycler (Techne, Staffordshire, U.K.) and consisted of following steps: $94^{\circ} \mathrm{C}$ for $5 \mathrm{~min}, 28-32$ cycles at $94^{\circ} \mathrm{C}$ for $30 \mathrm{sec}$; optimized annealing temperature for $30 \mathrm{sec}$ and $72^{\circ} \mathrm{C}$ for $10 \mathrm{~min}$ (elongation). The amount of cDNA was normalized to the intensity of the PCR products of the ubiquitously expressed gene porphobilinogen deaminase (PBGD). PCR products were separated on a $1 \%$ agarose gel and visualized using ethidium-bromide (Roth, Karlsruhe, Germany). All RT-PCRs were performed in independent triplicates.

\section{Western blotting}

For protein extraction, $10^{6}$ cells were lysed in precooled Ripa-buffer (Pierce, Rockford, Ilinois) containing phosphatase inhibitors (Phosphatase Inhibitor Cocktails Set II, Calbiochem, Germany), proteinase inhibitors (Complete, Roche, Germany) and 2,5 mM DTT reducing agent (Dithiothreitol, Sigma, Taufkirchen, Germany). The mixture was incubated for $30 \mathrm{~min}$ on ice, combined with vortexing every $10 \mathrm{~min}$. Cell lysates were clarified of cell debris by centrifugation at $14.000 \times \mathrm{g}$ for $5 \mathrm{~min}$ through a QIAshredder spin column assembly (Qiagen) at $4^{\circ} \mathrm{C}$. Protein concentration was determined by the Bradfordmethod [47] using coomassie brilliant blue (Roti-Quant; Roth, Karlsruhe, Germany). Afterwards, the samples were mixed in $5 \times$ loading buffer (Fermentas), denatured at $95^{\circ} \mathrm{C}$ for $5 \mathrm{~min}$, chilled on ice and stored at $-20^{\circ} \mathrm{C}$ for further analysis. Equal amounts of proteins $(20 \mu \mathrm{g})$ were loaded on a $10 \%$ polyacrilamide gel (SDS-PAGE) and electrophoresed. Proteins were then blotted onto a nitrocellulose membrane (Schleicher \& Schuell, Dassel, Germany) for $45 \mathrm{~min}$ at $10 \mathrm{~V}$ using a semi-dry-transfer unit (PeqLab, Erlangen, Germany). The membrane was stained with ponceau-red (Sigma) to verify that the proteins were 
Table 1 Human gynecological cell lines

\begin{tabular}{|c|c|c|c|c|c|}
\hline Cell line & Tissue & Cell type & Origin & Special features & Citation \\
\hline Ishikawa & Endometrium & Adenocarcinoma & Primary tumor & $\begin{array}{l}\text { ER positive, } \\
\text { PR positive }\end{array}$ & {$[20-22]$} \\
\hline HEC-1-A & Endometrium & Adenocarcinoma & Primary tumor & $\begin{array}{l}\text { ER positive } \\
\text { PR positive }\end{array}$ & {$[23-25]$} \\
\hline AN3-CA & Endometrium & Adenocarcinoma & $\begin{array}{l}\text { Metastatic site } \\
\text { (lymph node) }\end{array}$ & $\begin{array}{l}\text { ER positive } \\
\text { PR positive }\end{array}$ & {$[26-28]$} \\
\hline HeLa & Cervix & Adenocarcinoma & Primary tumor & HPV-18 positive & {$[29-31]$} \\
\hline Caski & Cervix & $\begin{array}{l}\text { Epidermoid } \\
\text { carcinoma }\end{array}$ & $\begin{array}{l}\text { Metastasis } \\
\text { (small bowel mesentery) }\end{array}$ & $\begin{array}{l}\text { HPV-16 positive } \\
\text { HPV-18 positive }\end{array}$ & {$[32,33]$} \\
\hline $\mathrm{SiHa}$ & Cervix & $\begin{array}{l}\text { Squamous cell } \\
\text { carcinoma }\end{array}$ & Primary tumor & HPV-16 positive & {$[34,35]$} \\
\hline JEG & Placenta & Chorioncarcinoma & Primary tumor & Produce hCG, HCS, progesterone & {$[36,37]$} \\
\hline JAR & Placenta & Chorioncarcinoma & Primary tumor & Produce estrogen, progesterone, hCG, HCS & [38] \\
\hline BeWo & Placenta & Chorioncarcinoma & $\begin{array}{l}\text { Metastatic site (cerebral } \\
\text { metastasis) }\end{array}$ & $\begin{array}{l}\text { Produce estrogen, progesterone, hCG, HCS, estrone, estriol, } \\
\text { estradiol, keratin }\end{array}$ & {$[38-40]$} \\
\hline BG_1 & Ovary & Adenocarcinoma & Primary tumor & $\begin{array}{l}\text { ER positive } \\
\text { PR positive }\end{array}$ & {$[41,42]$} \\
\hline OAW 42 & Ovary & Cystadenocarcinoma & Metastatic site (ascites) & & {$[43,44]$} \\
\hline PA1 & Ovary & Teratocarcinoma & Metastatic site (ascites) & & {$[45]$} \\
\hline
\end{tabular}

blotted. To avoid unspecific binding, the membrane was blocked with $5 \%$ nonfat milk in PBS/Tween $(0,05 \%)$ at RT for 1 hour. Subsequently, the membrane was incubated with the primary antibody at appropriate dilution in $2 \%$ nonfat milk and PBS/Tween at $4^{\circ} \mathrm{C}$ for 18 hours. Primary antibodies used are summarized in Table 2. After washing with PBS, the membrane was incubated with the respective horseradish peroxidase-conjugated secondary antibodies for $60 \mathrm{~min}$ at RT. A monoclonal mouse anti- $\beta$-actin primary antibody, diluted 1: 10.000, (Abcam, Cambridge, USA) was used as internal control. Immunoblots were visualized by homemade enhanced chemiluminescence (ECL) [48] with subsequent exposure on an X-ray film (Fuji Super RX medical X-ray films; Fuji Photo Film, Duesseldorf, Germany).

\section{Gelatin zymography}

Cell supernatants were collected after 48 hours incubation in serum-free medium. Enzymatic activity of MMP-2 and MMP-9 was measured by gelatinolytic zymography. Conditioned media $(20 \mu \mathrm{l})$ were incubated with SDS gel sample buffer (Invitrogen, Carlsbad, USA) for 10 minutes at room temperature and electrophoresed on 10\% Novex precast zymogram (gelatin) gels (Invitrogen). The gels were run, renatured and developed according to the manufacturer's instructions. Briefly, after electrophoresis, the gels were rinsed twice with Novex Zymogram Renaturing Buffer (30 minutes per wash at room temperature). The gels were then rinsed with fresh Novex Zymogram Developing Buffer and incubated in the same buffer for 18 hours at $37^{\circ} \mathrm{C}$. After incubation, the gels were briefly rinsed in distilled water and stained with Coomassie brilliant blue G250 for 2 hours. The digested area appeared clear on a blue background, indicating the expression and activity of gelatinases. The molecular weights of the gelatinases in the samples were determined using recombinant protein molecular weight markers MMP-2 and MMP-9 (R\&D Systems, Wiesbaden, Germany).

Table 2 List of antibodies used for Western blot

\begin{tabular}{|c|c|c|c|c|c|}
\hline Gene & $\begin{array}{l}\text { Protein forms } \\
\text { detected by } \\
\text { WB* }\end{array}$ & Species & Type/clone & Dilution & Company \\
\hline MMP-1 & $\begin{array}{l}\text { latent and } \\
\text { active }\end{array}$ & rabbit & polyclonal & $1: 750$ & Biozol \\
\hline MMP-2 & $\begin{array}{l}\text { latent and } \\
\text { active }\end{array}$ & rabbit & polyclonal & 1: 1000 & Abcam \\
\hline MMP-9 & $\begin{array}{l}\text { latent and } \\
\text { active }\end{array}$ & mouse & $9 D 4.2$ & 1: 500 & Chemicon \\
\hline $\begin{array}{l}\text { MMP- } \\
11\end{array}$ & $\begin{array}{l}\text { latent and } \\
\text { active }\end{array}$ & mouse & SL 3.01 & 1: 500 & Abcam \\
\hline $\begin{array}{l}\text { MMP- } \\
13\end{array}$ & $\begin{array}{l}\text { latent and } \\
\text { active }\end{array}$ & mouse & 87512 & 1: 500 & $R \& D$ \\
\hline $\begin{array}{l}\text { MMP- } \\
15\end{array}$ & $\begin{array}{l}\text { latent and } \\
\text { active }\end{array}$ & rabbit & polyclonal & 1: 500 & Abcam \\
\hline $\begin{array}{l}\text { MMP- } \\
23\end{array}$ & $\begin{array}{l}\text { latent and } \\
\text { active }\end{array}$ & rabbit & polyclonal & 1: 1000 & Abcam \\
\hline $\begin{array}{l}\text { MMP- } \\
24\end{array}$ & $\begin{array}{l}\text { latent and } \\
\text { active }\end{array}$ & rabbit & polyclonal & 1: 1000 & Abcam \\
\hline $\begin{array}{l}\text { MMP- } \\
28\end{array}$ & not specified & rabbit & polyclonal & 1: 1000 & Abcam \\
\hline$\beta$-actin & & mouse & $\begin{array}{l}\text { M/Abcam } \\
8226\end{array}$ & $\begin{array}{l}1: \\
10.000\end{array}$ & Abcam \\
\hline
\end{tabular}

*WB: Western blot. 


\section{Data analysis and statistics}

The intensity of ethidium-bromide luminescence and protein expression in Western Blot images was quantified densitometrically using ImageJ image-processing software package (Image): National Institutes of Health, Bethesda, MD, USA), as abovementioned, and normalized in respect to the corresponding fragment concentration of the ubiquitously expressed genes PBGD and $\beta$-actin. Four different expression levels were considered in respect of their densitometric value. Value 0 was considered to be no expression. Values between 1 and 19 were considered as very weak $((+))$, between 20 and 49 as weak $(+)$, between 50 and 79 as moderate $(++)$ and between 80 and 100 as high $(+++)$ expression.

\section{Results}

\section{Expression of MMP mRNA in different gynecological} cancer cell lines

A varying expression pattern of MMPs could be observed on an mRNA level, depending on the cell line investigated. Except for MMP-16, -20, -25, -26 and -27, mRNA could be detected for all other MMPs in at least one of the cell lines. For MMP-8, -12 and -21 only very weak mRNA expression could be observed in single cell lines. Nine MMPs, which were present in most of the cell lines, were chosen for further expression analysis on protein level. The results of the semiquantitative RT-PCR and Western blot are summarized in Figures 1 and 2. The results of the densitometrically quantified expression of the mRNAs and proteins are shown in Table 3 and 4, respectively. The enzymatic activity of two gelatinases (MMP-2 and -9) in the serum-free cell culture supernatants was examined by gelatin zymography and the corresponding data is presented in Figure 3.

\section{Expression of MMPs in endometrial cancer cell lines}

In the Ishikawa cell line, the highest expression was detected for MMP-2 and -11 on an mRNA level, but only a weak expression of their proteins could be observed in the cell lysates. However, moderate gelatinolytic activity of the secreted latent form of MMP- 2 could be identified by gelatin zymography, whereas its active form showed very weak activity. For MMP-23, moderate mRNA and strong expression of its inactive protein was seen in the same cell line. Albeit the highest expression of MMP-24 mRNA was detected in Ishikawa cells, on Western blot its expression was weaker compared to other two endothelial cancer cell lines. In Ishikawa, the expression of MMP-28 both on mRNA as well as on protein level was weaker compared to the two other endothelial cancer cell lines. In addition, MMP-7, -14, -17 and -19 were detected in the Ishikawa cells by RT-PCR only.

Although the highest expression of MMP-11 mRNA was identified in the HEC-1-A cells, no protein expression was detectable in this cell line. The same cell line showed a weak expression of MMP-2 on mRNA level, a moderate expression on protein level as well as corresponding gelatinolytic activity of its secreted protein. Even though the expression of MMP-23 mRNA was the weakest among endometrial cancer cell lines, for its inactive form as well as active protein strong expression was observed. A high expression of proteins of approximately $65 \mathrm{KDa}$ and 55 KDa could be identified for MMP-24 in HEC-1-A cells, whereas for MMP-28 a strong expression of three protein bands of approximately $62 \mathrm{KDa}, 58 \mathrm{KDa}$ and $48 \mathrm{KDa}$ could be seen. Additionally, very weak expression of MMP-1 and - 7 could be also detected in this cell line, but only on mRNA level.

The highest expression of active forms of MMP-2 and -11 proteins among the three examined endometrial cell lines was detected in AN3 CA cells, although for MMP2 only a weak mRNA expression could be identified. In this cell line, MMP-23 showed similar mRNA and protein expression patterns like in HEC-1-A. For MMP-24 and -28 the expression was detected on both, mRNA and protein level, whereas for MMP-1 and -17 only mRNA could be identified.

\section{Expression of MMPs in cervical cancer cell lines}

The majority of the analyzed MMPs could be identified in all three cervical cell lines examined by RT-PCR. While for MMP-2 a moderate to strong expression of its mRNA could be found in HeLa, Caski and $\mathrm{SiHa}$ cells, on protein level a very strong expression of its inactive form was detected by Western blot. In addition, using gelatin zymography we showed that all three of these cultivated cell lines were secreting corresponding amount of the latent form of MMP-2 in serum-free medium. Furthermore, MMP-1, -3, -7, -8, -9, -11, -13, $-14,-15,-17,-23$ and -24 all showed diverse expression levels of their mRNAs with the highest expression level in the Caski cell line. Active protein forms of MMP-1 and -11 , inactive protein form of MMP-15, and both inactive and active MMP-9, -13 and -23 were observed on Western blot. For MMP-24, we were able to detect a band of approximately $65 \mathrm{KDa}$ in Caski and an additional band of approximately $55 \mathrm{KDa}$ in HeLa cells. Lastly, all three cervical cancer cell lines four protein bands of approximately 62, 50, 48 and $46 \mathrm{kDa}$ were found for MMP-28.

\section{Expression of MMPs in chorioncarcinoma cell lines}

Albeit a clear expression existed of MMP-2, -9, -11, -14 and -19 mRNAs in the JEG cell line, their proteins could not be detected using Western blot analysis. The only proteins found in this cell line were the latent forms of MMP-15 and -23 at moderate levels corresponding to the expression of their mRNAs. 


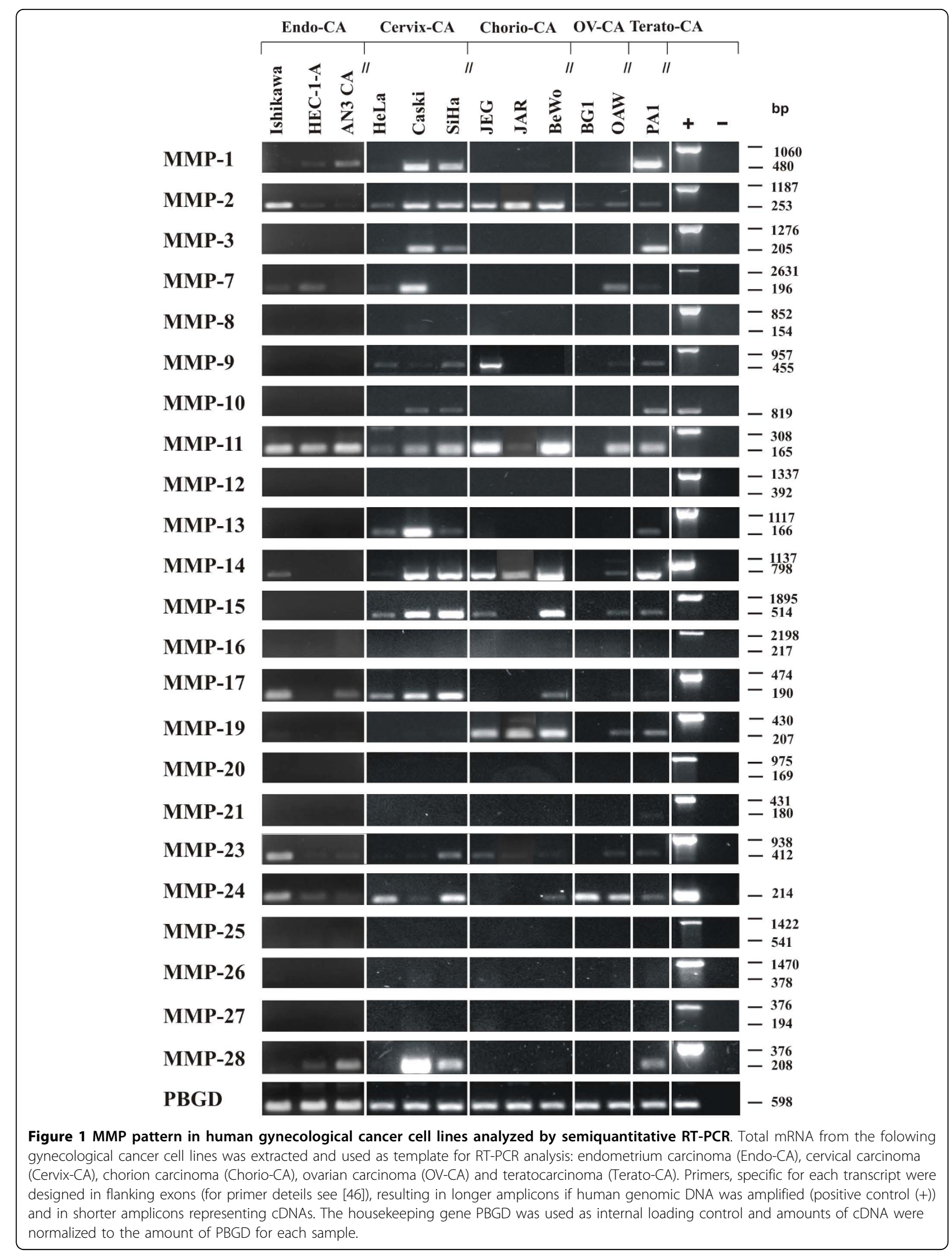




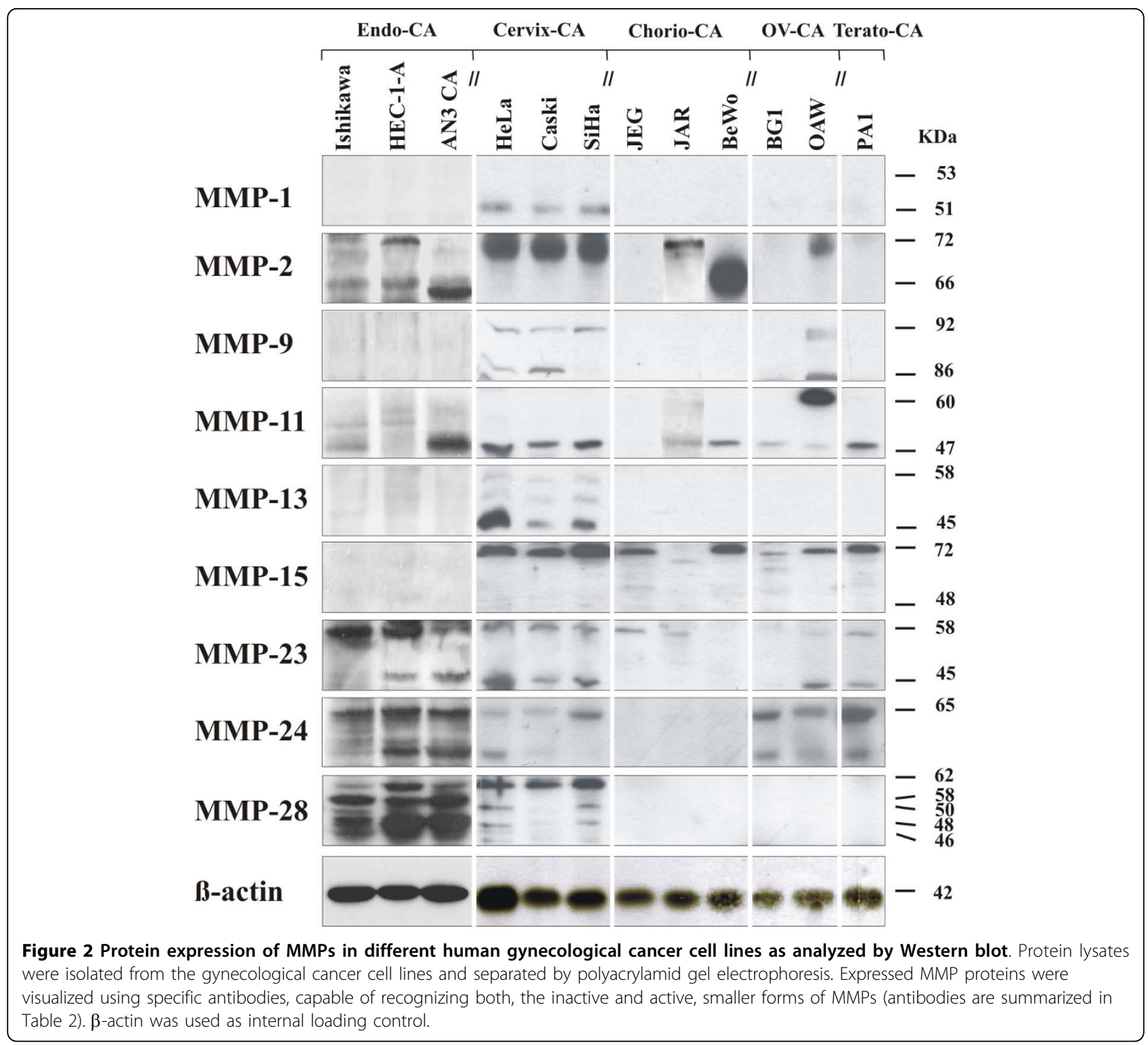

A strong expression of MMP-2 mRNA was detected in JAR cells. Extremely robust gelatinolytic activity of its secreted protein could be identified in the serum-free medium, whereas on Western blot only a moderate protein expression of the inactive form could be seen in the cells. Active MMP-9 showed very weak gelatinolytic activity, although on Western blot no expression could be seen. Weak expression of both mRNAs and inactive protein forms of MMP-11 and -23 could also be identified in this cell line. In addition, expression of MMP-14 and -19 was detected but only on mRNA level.

The highest expression found in all cell lines tested of the active protein forms of MMP-2 and - 11 was detected in BeWo cells. Gelatin zymography also revealed activity of MMP-2 secreted by BeWo cells. For MMP-15, a strong expression of its mRNA was present but the latent protein form could only be detected in those cells. Further, solely MMP-14, $-17,-19$ and -24 could be identified by RT-PCR only.

\section{Expression of MMPs in ovarian and teratocarcinoma cell lines}

A strong expression of the mRNA and protein (approximately $65 \mathrm{KDa}$ and $55 \mathrm{KDa}$ ) of MMP-24 was found in the ovarian carcinoma derived BG1 cells. Rather, a weak expression of MMP-2 and -11 was also seen on Western blot in this cell line.

For MMP-2, -15 and -24, a moderate expression of mRNAs and latent protein forms were detected in the OAW-42 cell line. Regarding OAW-42 cells, MMP-11 
Table 3 Expression levels of MMP mRNA in gynecological cancer cell lines

\begin{tabular}{|c|c|c|c|c|c|c|c|c|c|c|c|c|}
\hline & Ishikawa & HEC-1-A & AN3 CA & Hela & Caski & $\mathrm{SiHa}$ & JEG & JAR & BeWo & BG-1 & OAW-42 & PA1 \\
\hline MMP1 & 0 & $(+)$ & + & $(+)$ & +++ & +++ & 0 & 0 & 0 & 0 & $(+)$ & +++ \\
\hline MMP2 & +++ & + & $(+)$ & + & +++ & +++ & +++ & +++ & +++ & $(+)$ & + & + \\
\hline MMP3 & 0 & 0 & 0 & $(+)$ & +++ & ++ & 0 & 0 & 0 & 0 & 0 & +++ \\
\hline MMP7 & $(+)$ & + & $(+)$ & $(+)$ & +++ & 0 & 0 & 0 & 0 & 0 & ++ & $(+)$ \\
\hline MMP8 & 0 & 0 & 0 & 0 & $(+)$ & 0 & 0 & 0 & 0 & 0 & 0 & 0 \\
\hline MMP9 & 0 & 0 & 0 & $(+)$ & $(+)$ & + & +++ & 0 & 0 & 0 & $(+)$ & + \\
\hline MMP10 & 0 & 0 & 0 & 0 & + & + & 0 & 0 & 0 & 0 & 0 & ++ \\
\hline MMP11 & ++ & ++ & ++ & + & ++ & ++ & +++ & + & +++ & $(+)$ & ++ & ++ \\
\hline MMP12 & 0 & 0 & 0 & 0 & $(+)$ & 0 & 0 & 0 & 0 & 0 & 0 & 0 \\
\hline MMP13 & 0 & 0 & 0 & + & +++ & + & 0 & 0 & 0 & 0 & 0 & + \\
\hline MMP14 & + & 0 & 0 & $(+)$ & +++ & +++ & +++ & ++ & +++ & 0 & + & +++ \\
\hline MMP15 & 0 & 0 & 0 & + & +++ & +++ & + & 0 & +++ & 0 & + & + \\
\hline MMP16 & 0 & 0 & 0 & 0 & 0 & 0 & 0 & 0 & 0 & 0 & 0 & 0 \\
\hline MMP17 & ++ & 0 & + & + & ++ & ++ & 0 & 0 & + & 0 & $(+)$ & $(+)$ \\
\hline MMP19 & $(+)$ & 0 & 0 & 0 & 0 & 0 & +++ & +++ & +++ & 0 & + & ++ \\
\hline MMP20 & 0 & 0 & 0 & 0 & 0 & 0 & 0 & 0 & 0 & 0 & 0 & 0 \\
\hline MMP21 & 0 & 0 & 0 & 0 & 0 & 0 & 0 & 0 & 0 & 0 & 0 & $(+)$ \\
\hline MMP23 & ++ & 0 & 0 & $(+)$ & $(+)$ & ++ & + & $(+)$ & $(+)$ & 0 & $(+)$ & $(+)$ \\
\hline MMP24 & ++ & + & $(+)$ & ++ & $(+)$ & ++ & 0 & 0 & + & ++ & ++ & + \\
\hline MMP25 & 0 & 0 & 0 & 0 & 0 & 0 & 0 & 0 & 0 & 0 & 0 & 0 \\
\hline MMP26 & 0 & 0 & 0 & 0 & 0 & 0 & 0 & 0 & 0 & 0 & 0 & 0 \\
\hline MMP27 & 0 & 0 & 0 & 0 & 0 & 0 & 0 & 0 & 0 & 0 & 0 & 0 \\
\hline MMP28 & $(+)$ & + & ++ & $(+)$ & +++ & ++ & 0 & 0 & 0 & 0 & 0 & ++ \\
\hline
\end{tabular}

Scored from $0=$ no expression, $(+)=$ very weak expression, $+=$ weak expression, $++=$ moderate expression to $+++=$ high expression.

Table 4 Expression of MMP proteins in different gynecological cancer cell lines

\begin{tabular}{|c|c|c|c|c|c|c|c|c|c|c|c|c|}
\hline & Ishikawa & HEC-1-A & AN3 CA & Hela & Caski & $\mathrm{SiHa}$ & JEG & JAR & BeWo & BG-1 & OAW-42 & PA1 \\
\hline proMMP1 & 0 & 0 & 0 & 0 & 0 & 0 & 0 & 0 & 0 & 0 & 0 & 0 \\
\hline MMP1 & 0 & 0 & 0 & + & + & + & 0 & 0 & 0 & 0 & 0 & 0 \\
\hline proMMP2 & $(+)$ & + & $(+)$ & +++ & +++ & +++ & 0 & + & 0 & 0 & ++ & 0 \\
\hline MMP2 & + & + & ++ & 0 & 0 & 0 & 0 & 0 & +++ & 0 & 0 & 0 \\
\hline proMMP9 & 0 & 0 & 0 & + & + & + & 0 & 0 & 0 & 0 & + & 0 \\
\hline MMP9 & 0 & 0 & 0 & + & ++ & 0 & 0 & 0 & 0 & 0 & ++ & 0 \\
\hline proMMP11 & 0 & $(+)$ & $(+)$ & 0 & 0 & 0 & 0 & + & 0 & 0 & +++ & 0 \\
\hline MMP11 & + & 0 & +++ & ++ & + & ++ & 0 & + & + & $(+)$ & $(+)$ & + \\
\hline proMMP13 & 0 & 0 & 0 & $(+)$ & $(+)$ & $(+)$ & 0 & 0 & 0 & 0 & 0 & 0 \\
\hline MMP13 & 0 & 0 & 0 & +++ & $(+)$ & ++ & 0 & 0 & 0 & 0 & 0 & 0 \\
\hline proMMP15 & 0 & 0 & 0 & ++ & ++ & +++ & + & 0 & ++ & $(+)$ & + & ++ \\
\hline MMP15 & 0 & 0 & 0 & $(+)$ & 0 & 0 & 0 & 0 & 0 & 0 & 0 & 0 \\
\hline proMMP23 & +++ & +++ & ++ & ++ & + & + & + & $(+)$ & 0 & 0 & $(+)$ & + \\
\hline MMP23 & $(+)$ & ++ & ++ & +++ & + & ++ & 0 & 0 & 0 & 0 & ++ & + \\
\hline proMMP24 & + & ++ & ++ & + & + & ++ & 0 & 0 & 0 & ++ & + & +++ \\
\hline MMP24 & $(+)$ & ++ & ++ & + & $(+)$ & 0 & 0 & 0 & 0 & + & + & + \\
\hline MMP28(62) & + & +++ & ++ & ++ & ++ & +++ & 0 & 0 & 0 & 0 & 0 & 0 \\
\hline MMP28(58) & +++ & +++ & +++ & 0 & 0 & 0 & 0 & 0 & 0 & 0 & 0 & 0 \\
\hline MMP28(50) & + & 0 & 0 & + & 0 & + & 0 & 0 & 0 & 0 & 0 & 0 \\
\hline MMP28(48) & ++ & +++ & +++ & + & 0 & + & 0 & 0 & 0 & 0 & 0 & 0 \\
\hline MMP28(46) & + & ++ & ++ & $(+)$ & 0 & $(+)$ & 0 & 0 & 0 & 0 & 0 & 0 \\
\hline
\end{tabular}

Scored from $0=$ no expression, $(+)=$ very weak expression, $+=$ weak expression, $++=$ moderate expression to $+++=$ high expression. 


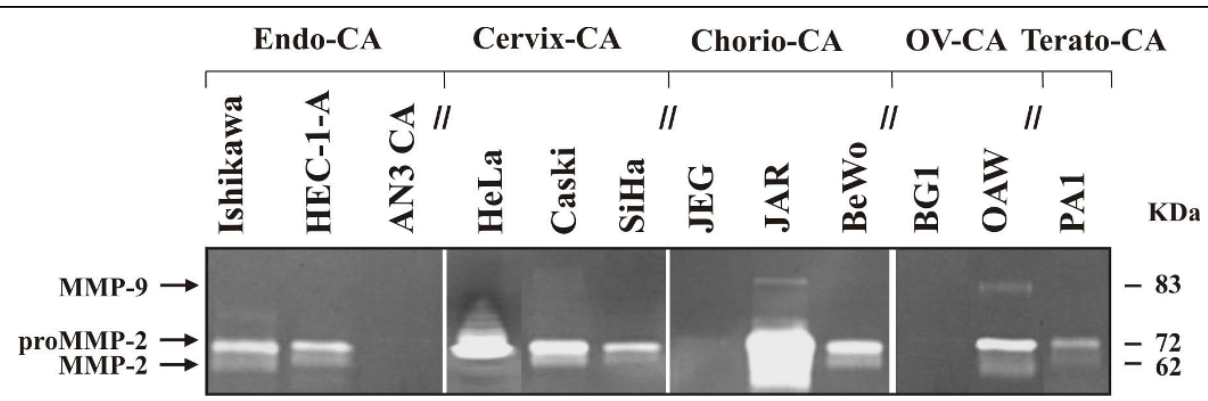

Figure 3 Analysis of the cell culture supernatants by gelatin zymography. The cell lines were first plated in serum-containing medium for $72 \mathrm{~h}$. Afterwards, medium was replaced by serum-free DMEM/HamsF12 for an additional $48 \mathrm{~h}$. Samples of conditioned medium were assayed for MMP-2 and MMP-9 by gelatin zymography. Gelatinolytic activity of pro and active MMP-2 and active MMP-9 are visible as a clear area on the gel, indicating where the gelatine has been digested.

showed strong expression of its inactive protein whereas for MMP-9 and -24 moderate expressions of both inactive and active proteins were identified. Zymographic analysis of the serum-free cell culture supernatant identified strong gelatinolytic activity of latent MMP-2 as well as weak activity of active MMP-9. Additionally, expression of MMP-7, -14 and -19 was detected on a mRNA level.

The highest expression was detected for MMP-1 on mRNA level in the teratocarcinoma cell line PA-1 but no corresponding protein expression could be detected by Western blot analysis. Secreted MMP-2 showed weak gelatinolytic activity. For MMP-11 moderate mRNA and protein expression was seen in this cell line and moderate expression of MMP-15 mRNA and inactive protein form could be observed herein, whereas for MMP-23 a weak expression could be observed by RT-PCR and Western blot. Although only a weak expression of MMP-24 mRNA was detected in PA-1 cells, a strong expression of two protein bands of $65 \mathrm{KDa}$ and approximately $55 \mathrm{KDa}$ were seen in Western blot. The PA-1 cell line was the only one amongst the investigated cell panel which showed a weak PCR product for MMP-21.

\section{Discussion}

Degradation of the extracellular matrix is a condition for invasive growth of malignant tumors. Metalloproteinases (MMPs) play a very important role in this process. The role and the contribution of the tumor and stromal cell compartments to the increased levels of MMPs in carcinoma tissue are still poorly understood. Some investigators suggest an almost exclusive stromal origin of MMPs detected in cancer tissue [1]. Other studies demonstrate that a lot of MMPs are constitutively expressed in several tumor cell lines in the absence from any stromal component [18]. Our objective was to investigate which MMPs are expressed in different gynecological cancer cell lines and thus to identify useful model system for further analysis on MMP regulation in cancer.

MMP-2, -7 and -9 were found to be expressed in uterine serous carcinoma as well as in endometrioid carcinoma of the uterus by immunohistochemistry [49]. The endometrial carcinoma derived cell line Ishikawa was shown to secrete MMP-1, -2 and -9 [50]. However in our Ishikawa cell line, mRNA and protein could be detected for MMP-2 but not for MMP-1 and -9, which could be influenced by different primers used or different cell culture conditions that might affect MMP expression. MMP-1 was described in HEC-1-A and AN3 CA cells [24] and in those cell lines we found a corresponding expression of its mRNA. However, no expression could be identified for MMP-1 protein in those endometrial cell lines. Our results confirm those of Park et al., who did not detect MMP-9 mRNA in HEC-1-A cells using RT-PCR [51]. Whereas in contrast to our negative findings by Western Blot, MMP-1, -2, -7, -9 and -14 protein could be detected in HEC-1-A cells using immunohistochemistry by Tanaka [52]. These differences might be due to different culture conditions or primers and antibodies (and techniques - WB versus immunohistochemsitry) used. Also, mRNA stability of MMP transcripts contributes to the metalloproteinase product amount. There is evidence about the regulation of the MMP-9 mRNA stability by $\alpha 3 \beta 1$ integrin, among others, that is associated with mammary carcinoma cell metastasis and invasion [53,54]. Modulation of its mRNA stability might be important during malignant conversion and metastasis, when tumor cells need to induce or maintain MMP-9 levels in response to changing environmental cues. In endometrial cancer, a high expression of MMP-2 and low expression of TIMP-2 seem to be potent markers for tumors, which provide a high risk of local and distant metastasis [55]. In our study MMP-2 mRNA as well as MMP-2 protein was found in all three endometrial cancer cell lines. We also identified moderate gelatinolytic 
activity of MMP-2 protein that was secreted by Ishikawa and HEC-1-A cells. Expession analysis of TIMPs, including TIMP-2, remains to be done however in our endometrial cancer cell lines. A relation between higher expression of MMP-2 and -9 and progression of endometrial carcinoma was detected by Di Nezza et al. using in situ hybridization and in situ zymography. MMP-2, -9 and -14 were mainly localized in epithelial tumor cells, whereas only a variable stromal localization could be detected [56]. They also found a co-localization of MMP14 with MMP-2, supporting the role of MMP-14 in the activation of pro-MMP-2. In our cell lines, only Ishikawa was found positive for MMP-14 mRNA. However, protein detection in the Western blot was not possible by the antibodies available. Maximum levels of MMP-26 mRNA were found in normal endometrial tissue and in endometrial hyperplasia, whereas the amount of MMP26 mRNA was downregulated in all malignant samples investigated [57]. Consequently, in our study none of the tested endometrial cancer cell lines was positive for MMP-26 mRNA. This finding further fits to the data by Isaka and co-workers, where all but one endometrial tissue sample as well as all endometrial cancer cell lines including HEC-1-A were negative for MMP-26 mRNA [58]. In contrast to our results, as we found a weak expression of MMP-7 mRNA in HEC-1-A cells, they did not detect MMP-7 mRNA in this cell line. This difference might be due to either different primers or conditions used, or to different cell culture conditions that may influence MMP expression [59]. To the best of our knowledge, there are no available data in literature about the expression of the other MMPs in endometrial cancer cell lines. According to our results, the Ishikawa cell line showed the broadest range of mRNA and protein expression of most of the MMPs analyzed and thus could be the best choice as model cell line for future experiments on the role of MMPs in endometrial carcinoma development and as a positive control for MMP research. The expression of MMP-11, -23, -24 and -28, which was identified in our study on both, mRNA and protein level, could be related to the development of endometrial carcinoma and awaits further investigation in this cancer entity. Remarkably, the expression of MMP-23 protein was however on higher level compared to its mRNA, which might be due to increased efficiency of MMP-23 translation in endometrial cancer. Using the antibody for MMP-28 we detected bands of approximately $62,58,50$, 48 and $46 \mathrm{kDa}$. However, we did not have enough data to discriminate inactive and active forms of this protein since there is barely any information about its protein size. At least three MMP-28 transcripts of 2.6, 2.0, and $1.2 \mathrm{~kb}$ have been reported representing alternatively spliced forms, differentially expressed in human tissues
[60] and isoforms which encode proteins of 520 and 393 amino acids with predicted respective masses of 58.9 and $44.5 \mathrm{kDa}$.

In the cervix, it was shown that MMP-2, -3 and -9 are present in the tissue of cervical adenocarcinomas, whereas no expression of these MMPs could be detected in the nonneoplastic endocervical epithelium [10]. In accordance to this, Wang et al. detected a higher expression of MMP-2 mRNA in cervical carcinomas then in normal counterparts of the uterine cervix [12] and we found MMP-2 mRNA in all three cervical carcinoma derived cell lines as well. We also found a strong expression of inactive MMP-2 in those cells using Western blot as well as a strong gelatinolytic activity of its secreted protein. The high expression of MMP-14 described by Zhai and colleagues in tissues of cervical carcinomas corresponds to our finding of strong mRNA expression in Caski and $\mathrm{SiHa}$ cell lines [13]. Further, we found a strong expression of MMP-15 mRNA in those cell lines. These results are in line with results obtained by Iwasaki et al. [19]. In contrast to our study Iwasaki and co-workers did not detect MMP-1 in Caski or SiHa cells, whereas we found a strong expression of MMP-1 mRNA and a weak expression of active MMP-1 in both cell lines. In HeLa cells, only few MMPs were expressed at lower amounts. Taken together the identified expression profile leads to the conclusion that future experiments on invasion of cervical cancer cells would be promising using Caski or SiHa cells as a model. In addition, since MMP-1, $-11,-13,-15,-17,-24$ and -28 are expressed in all three cervical carcinoma cell lines analyzed, these could be good candidates for further expression analysis in cervical carcinoma tissues as well.

To our knowledge, there are just few amount of data available about the expression of MMPs in chorioncarcinoma cell lines. In the JEG cell line we detected MMP-2, $-9,-11,-14,-15,-19$ and -23 mRNA whereas on protein level only weak expression of latent MMP-15 and -23 was observed. Giambernardi et al. also investigated the expression of the abovementioned MMPs in JEG cells and observed the expression of MMP-12 (which was negative in our results) and -14, but not the expression of the remaining MMPs [18]. These differences may be due to some variations in cell culture conditions (e.g. differences in serum containing growth factors added to the culture medium). We found a moderate to strong expression of MMP-2, $-11,-14,-15$ and -19 mRNA in BeWo cells, whereas on protein level only proMMP-15 and active MMP-2 and - 11 were detectable. In addition, our zymography analysis of secreted MMP-2 identified moderate gelatinolytic activity of its latent and active forms. These differences in the expression pattern between mRNA and protein level might be due to regulation of 
the translational level [61]. In line with our results, the expression of MMP-2 was already described in BeWo cells [62]. Our data about the expression pattern of MMPs in the JAR cell line showed a week to moderate expression of MMP-2, -11, -14, -19 and -23 on mRNA level, but only a weak expression of MMP-11 and -23 protein could be identified. However, for MMP-2 we were able to detect protein expression in the cells as well as very strong gelatinolytic activity of its secreted protein. Thus, based on our analysis, we suggest BeWo cells as the best model for future analyses of MMP biology and regulation in chorioncarcinoma cell lines.

In ovarian cancer, MMP-2 and -9 seem to be expressed more frequently in early lesions than in established carcinomas [14]. Overexpression of MMP-2, -9 and -14 seems to also prepare the ground for development and growth of malignant ovarian tumors [16]. According to these findings, MMPs might play a critical role in the first steps of tumorigenesis in ovaries. Surprisingly, to our knowledge, no single study to date investigated the expression of MMPs in the ovarian cancer cell lines OAW-42, BG-1 and in the teratocarcinoma cell line PA-1 compared to already performed examinations of endometrial, cervix or choriocarcinoma cancer cell lines, as already discussed. The PA- 1 cells do express a relatively broad range of 15 different MMP-RNAs. While on mRNA level only a weak expression of MMP-15 and -24 could be observed a moderate to strong expression of pro-MMP-15 and -24 proteins was detectable. Further, the active form of MMP- 11 and both, inactive and active forms of MMP-23 were detected. OAW-42 cells showed a remarkable high expression of MMP-11 as mRNA and protein. Further, mRNAs and proteins of MMP-2, -9, -15 and -23 were moderately expressed in this cell line. According to this finding we also detected gelatinolytic activity of secreted MMP-2 and MMP-9 by performing zymography analysis of the cell culture supernatant. Based on our data, there are many more MMPs beside the commonly investigated MMP-2, -9 and -14 , which are expressed in ovarian cancer cell lines and are thus candidates for future analyses on their influence on the development of ovarian cancer.

In our study we could not detect the mRNAs of MMP-12, -16, -20, -25, -26 and -27 in any of the twelve cell lines analyzed. However due to the genomic DNA control and the positive other MMPs in the same preparations, we could ascertain that the RT-PCR itself worked. Concerning MMP-20, these results are in line with results obtained by Giambernardi et al. who also did not detect MMP-20 in any of the eighty-four cell lines analyzed in their study [18].

In summary, we detected a broad and diverse expression pattern of MMPs in different cell lines representing different human gynecological cancer entities. Our data indicate that there is no real pattern of MMP expression related to cancer type or metastasis. Even within the same cancer stage MMPs have a diverse expression, as our previous analysis of breast cancer and glioblastoma showed $[46,63]$. Therefore, further studies on MMPs and a better understanding of their role in tumor invasion and metastasis are necessary. The results presented here could establish thus a basis for the analysis of the regulation of MMP expression in gynecological tumors, which could be performed in these cell lines selected as a model system.

\section{Conclusions}

This study demonstrates that gynecological cell lines grown in vitro and therefore being independent of environmental factors can constitutively express a wide variety of MMPs on mRNA and protein level. MMP-2, -11, -14 and -24 are found in most of the cell lines analyzed. MMP-1 and - 7 were expressed in all but chorioncarcinoma cells, whereas MMP-9 and -15 showed the same expression pattern concerning endometrial cancer cell lines. In addition, MMP-3, -10 and -13 were expressed in cervical carcinoma and teratocarcinoma cell lines only.

Caski and PA-1 cell lines could be the best choice for all future experiments on the regulation of MMPs and their role in gynecological cancers. Additionally, the PA1 cell line showed the strongest mRNA and protein expression of most of the MMPs analyzed and therefore could be used as the positive control for their expression analysis in general. These cell lines are also promising candidates for future investigations dealing with the role of MMPs in tumor invasion and building of metastatic formations. Although expression on mRNA and protein level was quite less in comparison to the abovementioned cell lines, BeWo cells could be the best choice for future experiments concerning chorioncarcinoma cell lines and the Ishikawa cell line concerning endometrial carcinoma, whereas OAW could be used for the ovarial cancer analysis.

\section{Additional material}

Additional file 1: MMP expression in gynecological cancer cell lines.

List of abbreviations

bp: base pare; DTT: dithiothreitol; ER: estrogen receptors; hCG: human chorionic gonadotropin; HCS: human chorionic somatomammotropin; HPV: human papillomavirus; kDa: kilodalton; MMPs: matrix metalloproteinases; PBGD: porphobilinogen deaminase; PBS: phosphate-buffered saline; PR: progesterone receptors; RT: reverse transcriptase; U: unit.

\section{Competing interests}

The authors declare that they have no competing interests. 


\section{Authors' contributions}

AS drafted the manuscript, set up the experiments, collected the data, analyzed and interpreted the results. UK participated in the study design, interpretation of the results and finalization of the manuscript. SF and MK carried out the PCR and Western Blot analysis. JD participated in editorial support. JA participated in the study design, experimental concept, interpretation of the results and drafting of the manuscript. All authors read and approved the final manuscript.

\section{Acknowledgements}

We thank Renate Bausch for technical assistance and Sonja Kaspar for help with language revision. This work was supported in parts by grant KFO-124 TP4 of the "Deutsche Forschungsgemeinschaft" to UK.

Received: 23 February 2010 Accepted: 13 October 2010

Published: 13 October 2010

\section{References}

1. Egeblad M, Werb Z: New functions for the matrix metalloproteinases in cancer progression. Nat Rev Cancer 2002, 2(3):161-174.

2. Nagase $H$, Visse $R$, Murphy $G$ : Structure and function of matrix metalloproteinases and TIMPs. Cardiovasc Res 2006, 69(3):562-73.

3. Page-McCaw A, Ewald AJ, Werb Z: Matrix metalloproteinases and the regulation of tissue remodelling. Nat Rev Mol Cell Biol 2007, 8(3):211-233.

4. Stamenkovic I: Extracellular matrix remodelling: the role of matrix metalloproteinases. J Pathol 2003, 200(4):448-464.

5. Forget MA, Desrosiers RR, Beliveau R: Physiological roles of matrix metalloproteinases: implications for tumor growth and metastasis. Can J Physiol Pharmacol 1999, 77(7):465-480.

6. Curran S, Dundas SR, Buxton J, Leeman MF, Ramsay R, Murray GI: Matrix metalloproteinase/tissue inhibitors of matrix metalloproteinase phenotype identifies poor prognosis colorectal cancers. Clin Cancer Res 2004, 10(24):8229-8234.

7. Sternlicht MD, Werb Z: How matrix metalloproteinases regulate cell behavior. Annu Rev Cell Dev Biol 2001, 17:463-516.

8. Shiomi T, Okada Y: MT1-MMP and MMP-7 in invasion and metastasis of human cancers. Cancer Metastasis Rev 2003, 22(2-3):145-52.

9. Tunuguntla R, Ripley D, Sang QX, Chegini N: Expression of matrix metalloproteinase-26 and tissue inhibitors of metalloproteinases TIMP-3 and -4 in benign endometrium and endometrial cancer. Gynecol Oncol 2003, 89(3):453-9.

10. Davidson B, Goldberg I, Liokumovich P, Kopolovic J, Gotlieb WH, LernerGeva L, Reder I, Ben-Baruch G, Reich R: Expression of metalloproteinases and their tissue inhibitors in adenocarcinoma of the uterine cervix. Int $J$ Gynecol Pathol 1998, 17(4):295-301.

11. Nuovo GJ, MacConnell PB, Simsir A, Valea F, French DL: Correlation of the in situ detection of polymerase chain reaction-amplified metalloproteinase complementary DNAs and their inhibitors with prognosis in cervical carcinoma. Cancer Res 1995, 55(2):267-275.

12. Wang PH, Ko JL, Tsai HT, Yang SF, Han CP, Lin LY, Chen GD: Clinical significance of matrix metalloproteinase-2 in cancer of uterine cervix: a semiquantitative study of immunoreactivities using tissue array. Gynecol Oncol 2008, 108(3):533-542.

13. Zhai Y, Hotary KB, Nan B, Bosch FX, Muñoz N, Weiss SJ, Cho KR: Expression of membrane type 1 matrix metalloproteinase is associated with cervical carcinoma progression and invasion. Cancer Res 2005, 65(15):6543-6550.

14. Cai KQ, Yang WL, Capo-Chichi CD, Vanderveer L, Wu H, Godwin AK, Xu XX: Prominent expression of metalloproteinases in early stages of ovarian tumorigenesis. Mol Carcinog 2007, 46(2):130-143.

15. Kamat AA, Fletcher M, Gruman LM, Mueller P, Lopez A, Landen CN Jr, Han L, Gershenson DM, Sood AK: The clinical relevance of stromal matrix metalloproteinase expression in ovarian cancer. Clin Cancer Res 2006, 12(6):1707-1714.

16. Sakata K, Shigemasa K, Nagai N, Ohama K: Expression of matrix metalloproteinases (MMP-2, MMP-9, MT1-MMP) and their inhibitors (TIMP-1, TIMP-2) in common epithelial tumors of the ovary. Int J Oncol 2000, 17(4):673-681.

17. Ripley D, Tunuguntla R, Susi L, Chegini N: Expression of matrix metalloproteinase- 26 and tissue inhibitors of metalloproteinase- 3 and -4 in normal ovary and ovarian carcinoma. Int J Gynecol Cancer 2006, 16(5):1794-800.
18. Giambernardi TA, Grant GM, Taylor GP, Hay RJ, Maher VM, McCormick JJ, Klebe RJ: Overview of matrix metalloproteinase expression in cultured human cells. Matrix Biol 1998, 16(8):483-496.

19. Iwasaki M, Nishikawa A, Fujimoto T, Akutagawa N, Manase K, Endo T, Yoshida K, Maekawa R, Yoshioka T, Kudo R: Anti-invasive Effect of MMI-166 New Selective Matrix Metalloproteinase Inhibitor, in Cervical Carcinoma Cell Lines. Gynecol Oncol 2002, 85(1):103-107.

20. Nishida M, Kasahara K, Kaneko M, Iwasaki H, Hayashi K: Establishment of a new human endometrial adenocarcinoma cell line, Ishikawa cells, containing estrogen and progesterone receptors. Nippon Sanka Fujinka Gakkai Zasshi 1985, 37(7):1103-1111.

21. Nishida M: The Ishikawa cells from birth to the present. Hum Cell 2002, 15(3):104-117.

22. Johnson SM, Maleki-Dizaji M, Styles JA, White IN: Ishikawa cells exhibit differential gene expression profiles in response to oestradiol or 4hydroxytamoxifen. Endocr Relat Cancer 2007, 14(2):337-350.

23. Kuramoto H, Tamura S, Notake Y: Establishment of a cell line of human endometrial adenocarcinoma in vitro. Am J Obstet Gynecol 1972, 114(8):1012-1019.

24. Kuramoto H, Hamano M, Imai M: HEC-1 cells. Hum Cell 2002, 15(2):81-95.

25. Navo MA, Smith JA, Gaikwad A, Burke T, Brown J, Ramondetta LM: In vitro evaluation of the growth inhibition and apoptosis effect of mifepristone (RU486) in human Ishikawa and HEC1A endometrial cancer cell lines. Cancer Chemother Pharmacol 2008, 62(3):483-9.

26. Dawe CJ, Banfield WG, Morgan WD, Slatick MS, Curth HO: Growth in continous culture, and in hamsters, of cell from a neoplasm associated with acanthosis nigricans. J Natl Cancer Inst 1964, 33:441-56.

27. Fogh J, Fogh JM, Orfeo T: One hundred and twenty-seven cultured human tumor cell lines producing tumors in nude mice. J Nat/ Cancer Inst 1977, 59:221-226.

28. Lesmeister MJ, Jorgenson RL, Young SL, Misfeldt ML: 17 Beta-estradiol suppresses TLR3-induced cytokine and chemokine production in endometrial epithelial cells. Reprod Biol Endocrinol 2005, 3:74.

29. Jones HW Jr, McKusick VA, Harper PS, Wuu KD: George Otto Gey. (18991970). The HeLa cell and a reappraisal of its origin. Obstet Gynecol 1971, 38:945-949.

30. Yee C, Krishnan-Hewlett I, Baker CC, Schlegel R, Howley PM: Presence and expression of human papillomavirus sequences in human cervical carcinoma cell lines. Am J Pathol 1985, 119:361-366.

31. Masters JR: HeLa cells 50 years on: the good, the bad and the ugly. Nat Rev Cancer 2002, 2(4):315-319.

32. Pattillo RA, et al: Tumor antigen and human chorionic gonadotropin in CaSki cells: a new epidermoid cervical cancer cell line. Science 1977, 196:1456-1458.

33. Pater MM, Pater A: Human papillomavirus types 16 and 18 sequences in carcinoma cell lines of the cervix. Virology 1985, 145:313-318.

34. Yee C, Krishnan-Hewlett I, Baker CC, Schlegel R, Howley PM: Presence and expression of human papillomavirus sequences in human cervical carcinoma cell lines. American Journal of Pathology 1985, 119:361-366.

35. Baker CC, Phelps WC, Lindgren V, Braun MJ, Gonda MA, Howley PM: Structural and transcriptional analysis of human papillomavirus type 16 sequences in cervical carcinoma cell lines. J Virol 1987, 61:962-971.

36. Kohler PO, Bridson WE: Isolation of hormone-producing clonal lines of human choriocarcinoma. J Clin Endocrinol Metab 1971, 32:683-687.

37. Kohler PO, Bridson WE, Hammond JM, Weintraub B, Kirschner MA, Van Thiel DH: Clonal lines of human choriocarcinoma cells in culture. Acta Endocrinol Suppl (Copenh) 1971, 153:137-153.

38. Patillo RA, Gey GO, Delfs E, Huang WY, Hause L, Garancis DJ, Knoth M Amatruda J, Bertino J, Friesen HG, Mattingly RF: The hormone-synthesizing trophoblastic cell in vitro: a model for cancer research and placental hormone synthesis. Ann N Y Acad Sci 1971, 172(10):288-298.

39. Hertz $\mathrm{R}$ : Choriocarcinoma of women maintained in serial passage in hamster and rat. Proc Soc Exp Biol Med 1959, 102:77-81.

40. Pattillo RA, Gey GO: The establishment of a cell line of human hormonesynthesizing trophoblastic cells in vitro. Cancer Res 1968, 28(7):1231-1236.

41. Geisinger KR, Kute TE, Pettenati MJ, Welander CE, Dennard Y, Collins LA, Berens ME: Characterization of a human ovarian carcinoma cell line with estrogen and progesterone receptors. Cancer 1989, 63(2):280-288.

42. Baldwin WS, Curtis SW, Cauthen CA, Risinger Jl, Korach KS, Barrett JC: BG-1 ovarian cell line: an alternative model for examining estrogendependent growth in vitro. In Vitro Cell Dev Biol Anim 1998, 34(8):649-654. 
43. Wilson AP: Characterization of a cell line derived from the ascites of a patient with papillary serous cystadenocarcinoma of the ovary. J Natl Cancer Inst 1984, 72(3):513-521.

44. Hill SM, Rodgers CS, Hultén MA, Wilson AP: Cytogenetics of a cell line derived from an ovarian papillary serous cystadenocarcinoma. Cancer Genet Cytogenet 1984, 12(4):321-327.

45. Zeuthen J, Nørgaard JO, Avner P, Fellous M, Wartiovaara J, Vaheri A, Rosén A, Giovanella BC: Characterization of a human ovarian teratocarcinoma-derived cell line. Int J Cancer 1980, 25(1):19-32.

46. Köhrmann A, Kammerer U, Kapp M, Dietl J, Anacker J: Expression of matrix metalloproteinases (MMPs) in primary human breast cancer and breast cancer cell lines: New findings and review of the literature. BMC Cancer 2009, 9:188.

47. Bradford MM: A rapid and sensitive method for the quantitation of microgram quantities of protein utilizing the principle of protein-dye binding. Anal Biochem 1976, 72:248-254.

48. Labjournal. [http://www.laborjournal.de/rubric/tricks/tricks/trick81.html].

49. Monaghan $\mathrm{H}$, MacWhinnie $\mathrm{N}$, Williams AR: The role of matrix metalloproteinases-2, -7 and -9 and beta-catenin in high grade endometrial carcinoma. Histopathology 2007, 50(3):348-57.

50. Sillem M, Prifti S, Koumouridis A, Runnebaum B: Invasiveness corresponds to differentiation rather than to proteinase secretion in endometrial cancer cell lines. Eur J Gynaecol Oncol 1999, 20(5-6):367-70.

51. Park DW, Ryu HS, Choi DS, Park YH, Chang KH, Min CK: Localization of matrix metalloproteinases on endometrial cancer cell invasion in vitro. Gynecol Oncol 2001, 82(3):442-449.

52. Tanaka R, Saito T, Ashihara K, Nishimura M, Mizumoto H, Kudo R: Threedimensional coculture of endometrial cancer cells and fibroblasts in human placenta derived collagen sponges and expression matrix metalloproteinases in these cells. Gynecol Oncol 2003, 90(2):297-304.

53. Lyer $V$, Pumiglia K, DiPersio CM: a3b1 integrin regulates MMP-9-mRNA stability in immortalized kerationcytes: A novel mechanism of integrinmediated MMP gene expression. J Cell Science 2005, 118:1185-1195.

54. Morini M, Mottolese M, Ferrari N, Ghiorzo F, Buglioni S, Mortarini R, Noonan DM, Natali PG, Albini A: The alpha 3 beta 1 integrin is associated with mammary carcinoma cell metastasis, invasion and gelatinase $B$ (MMP-9) activity. Int J Cancer 2000, 87:336-342.

55. Graesslin O, Cortez A, Uzan C, Birembaut P, Quereux C, Darai E: Endometrial tumor invasiveness is related to metalloproteinase 2 and tissue inhibitor of metalloproteinase 2 expressions. Int J Gynecol Cancer 2006, 16(5):1911-1917.

56. Di Nezza LA, Misajon A, Zhang J, Jobling T, Quinn MA, Ostör AG, Nie G, Lopata A, Salamonsen LA: Presence of active gelatinases in endometrial carcinoma and correlation of matrix metalloproteinase expression with increasing tumor grade and invasion. Cancer 2002, 94(5):1466-1475.

57. Pilka R, Norata GD, Domanski H, Andersson C, Hansson S, Eriksson P, Casslen B: Matrix metalloproteinase-26 (matrilysin-2) expression is high in endometrial hyperplasia and decreases with loss of histological differentiation in endometrial cancer. Gynecol Oncol 2004, 94(3):661-670.

58. Isaka K, Nishi H, Nakai H, Nakada T, Feng Li Y, Ebihara Y, Takayama M: Matrix Metalloproteinase-26 Is Expressed in Human Endometrium but not in Endometrial Carcinoma. Cancer 2003, 97(1):79-89.

59. Behrens I, Kissel T: Do cell culture conditions influence the carriermediated transport of peptides in Caco-2 cell monolayers? Eur J Pharm Sci 2003, 19(5):433-42.

60. Lohi J, Wolson CL, Roby JD, Parks WC: Epilysin, a novel human matrix metalloproteinase (MMP-28) expressed in testis and keratinocytes and in response to injury. J Biol Chem 2001, 276(13):10134-10144.

61. Gebauer F, Hentze MW: Molecular mechanisms of translational control. Nat Rev Mol Cell Biol 2004, 5(10):827-35.

62. Morgan M, Kniss D, McDonnell S: Expression of metalloproteinases and their inhibitors in human trophoblast continuous cell lines. Exp Cell Res 1998, 242(1):18-26.

63. Stojic J, Hagemann C, Haas S, Herbold C, Kühnel S, Gerngras S, Roggendorf W, Roosen $\mathrm{K}$, Vince $\mathrm{GH}$ : Expression of matrix metalloproteinases MMP-1, MMP-11 and MMP-19 I correlated with the WHO-grading of human malignant gliomas. Neurosci Res 2008, 60(1):40-49.

64. da Silva Cardeal LB, Brohem CA, Corrêa TC, Winnischofer SM, Nakano F, Boccardo E, Villa LL, Sogayar, Maria-Engler SS: Higher expression and activity of metalloproteinases in human cervical carcinoma cell lines is associated with HPV presence. Biochem Cell Biol 2006, 84(5):713-719.

65. Kato $Y$, Yamashita T, Ishikawa M: Relationship between expression of matrix metalloproteinase- 2 and matrix metalloproteinase- 9 and invasion ability of cervical cancer cells. Oncol Rep 2002, 9(3):565-569.

66. Mitra A, Chakrabarti J, Banerji A, Das S, Chatterjee A: Culture of human cervical cancer cells, $\mathrm{SiHa}$, in the presence of fibronectin activates MMP2. J Cancer Res Clin Oncol 2006, 132(8):505-513.

67. Zhang J, Cao YL, Zhao YG, Sang QX, Duan EK: Expression of matrix metalloproteinase-26 and tissue inhibitor of metalloproteinase-4 in human normal cytotrophoblast cells and a choriocarcinoma cell line, JEG-3. Mol Hum Reprod 2002, 8(7):659-666.

68. Di Simone N, Di Nicuolo F, Sanguinetti M, Ferrazzani S, D'Alessio MC, Castellani R, Bompiani A, Caruso A: Low-molecular weight heparin induces in vitro trophoblast invasiveness: role of matrix metalloproteinases and tissue inhibitors. Placenta 2007, 28(4):298-304

\section{Pre-publication history}

The pre-publication history for this paper can be accessed here: http://www.biomedcentral.com/1471-2407/10/553/prepub

doi:10.1186/1471-2407-10-553

Cite this article as: Schröpfer et al.: Expression pattern of matrix metalloproteinases in human gynecological cancer cell lines. $B M C$ Cancer 2010 10:553.

\section{Submit your next manuscript to BioMed Central and take full advantage of:}

- Convenient online submission

- Thorough peer review

- No space constraints or color figure charges

- Immediate publication on acceptance

- Inclusion in PubMed, CAS, Scopus and Google Scholar

- Research which is freely available for redistribution

Submit your manuscript at www.biomedcentral.com/submit
C Biomed Central 